\title{
SEGREGAÇÃO SOCIOESPACIAL: UMA META-ANÁLISE DOS TRABALHOS PUBLICADOS EM PERIÓDICOS A PARTIR DA APROVAÇÃO DO ESTATUTO DA CIDADE (2001-2017)
}

\author{
R. A. Bastos Filho, ${ }^{1, *}$, N. M. Almeida Pinto ${ }^{2}$, A. L. C. Fiúza ${ }^{3}$, V. A. M. Barros ${ }^{4}$ \\ 1,2,3,4 Universidade Federal de Viçosa \\ reinaldinhogestorufv@hotmail.com
}

Submetido 10/11/2017 - Aceito 39/12/2017

DOI: $10.15628 /$ holos.2017.6527

\section{RESUMO}

O presente trabalho objetivou examinar um conjunto de publicações que tiveram o conceito "segregação socioespacial" em seus títulos para, ao fim, elucidar o que de fato descrevem e analisam sobre a temática. Assim, para cumprimento de tal objetivo, como procedimento metodológico, utilizou-se os filtros: Portal de Periódicos da CAPES, Google Acadêmico e SciELO, com o intuito de pesquisar todos os artigos publicados entre 2001 e 2017. Após a verificação do material, 36 artigos foram selecionados. Em seguida, utilizou-se o software denominado Iramuteq para análise textual dos resumos e introduções desses trabalhos a fim de se verificar as temáticas e assuntos abordados. Os resultados apontam que os trabalhos apresentaram discussões divididas em duas categorias, que foram desmembradas em seguida em quatro grupos temáticos. As duas categorias foram denominadas: a
\end{abstract}

primeira "viés empírico", composta por artigos que possuem exposição de realidades locais através de pesquisas empíricas, e a segunda "viés teórico", composta por outra parte de artigos que buscaram reflexões sobre o conceito de segregação socioespacial. Finalmente, conclui-se que os dados do presente trabalho evidenciam informações que permitem oferecer direcionamento para pesquisadores da temática, uma vez que contribui com o estado da arte sobre o conceito. Em outras palavras, revela autores mais referenciados, periódicos que veiculam os trabalhos, objetivos dos trabalhos, métodos mais utilizados e por fim, seus assuntos e os focos de pesquisa, fornecendo assim, subsídios para novos estudos e aprofundamentos em aspectos que ainda podem ser explorados na academia.

\section{SOCIO-SPATIAL SEGREGATION: A META-ANALYSIS OF WORK PUBLISHED IN ACADEMIC JOURNALS SINCE FROM THE APPROVAL OF THE CITY STATUTE (2001- 2017)}

\begin{abstract}
The present work aimed to examine a set of publications that had the concept of "socio-spatial segregation" in their titles, in order to elucidate what they actually describe and analyze about the theme. In order to fulfill this objective, as a methodological procedure, the following filters were used: Portal de Periodicals of Capes, Google Academic and SciELO, with the intention of searching all articles published between 2001 and 2017. After the verification of the material, 36 works were selected. Next, the software named Iramuteq was used for textual analysis of the abstracts and introductions of these works to verify the themes and subjects covered. The results show that the papers presented discussions divided into two categories, which were then divided into four thematic groups.
\end{abstract}

The two categories were called "empirical bias", on the part of the articles that have an exposition of local realities through empirical research, and "theoretical bias", on the other part of the articles that seek reflections on the concept of sociospatial segregation. Finally, it is concluded that the data of the present work evidences information that allows to offer a direction to researchers of the thematic, since it contributes with the state of the art on the concept. In other words, it reveals more referenced authors, journals that publish the works, objectives, methods most used and, finally, their subjects and the focus of research, providing subsidies for new studies and deepening in subjects that still can be explored in the

academy. 


\section{INTRODUÇÃO}

Principalmente a partir da segunda metade do século $X X$, presenciamos no Brasil um crescimento muito veloz de nossas cidades. Como consequência desse processo de urbanização acelerado, tal expansão "empurrou" e gerou uma segregação socioespacial cada vez maior, que levou a classe trabalhadora para regiões periféricas, bem como transformou seletivamente o espaço intra-urbano em termos de acesso a serviços e infraestrutura, configurando o espaço urbano como um local importante na luta entre classes (GUIMARÃES, 2015 e VILLAÇA, 2001).

Essa "expulsão" e "disputa" por localidades fez com que as diferentes classes, ou camadas sociais, se concentrassem em diferentes regiões gerais ou conjuntos de bairros, estabelecendo um processo que Villaça (2001) chama de segregação. E, considerada uma forte marca e um problema grave das metrópoles brasileiras, a segregação socioespacial consequentemente faz emergir regiões ou bairros muito particulares, o que é considerado por Ermínia Maricato (2000) como sendo a expressão maior da exclusão social.

Buscando reduzir as grandes diferenças que existem entre os espaços dos ricos e dos pobres, é iniciada a partir dos anos 70, uma luta pela reforma urbana no Brasil. Com o movimento pela redemocratização do país nos anos 80 e 90, a reforma urbana ganha força na luta pela redução da segregação socioespacial, o que resultou, em 2001, na assinatura do Estatuto da Cidade e, mais tarde, em 2003, na criação do Ministério das Cidades (MARICATO, 1997; 2006).

Após estas conquistas (Estatuto da Cidade e Ministério das Cidades) advindas destes movimentos urbanos, busca-se compreender por meio do presente trabalho, o direcionamento dos estudos sobre a temática da segregação Socioespacial a partir destes momentos. Assim sendo, esse trabalho tomou como objeto de estudo as publicações que abordaram "segregação socioespacial" em seus títulos a partir do ano de 2001. Para tanto, buscou-se investigar o que está sendo tratado nessas publicações, na tentativa de compreender, por meio da meta-análise, quais as preocupações mais comuns no meio acadêmico no que se refere ao tema. Ou seja, buscou-se detectar quais as metodologias, objetivos, autores mais referenciados, os periódicos e seus respectivos Qualis CAPES, bem como verificar os anos em que foram publicados, para ao final, identificar as principais constatações acerca desse conjunto de materiais.

Para tanto, fez-se necessário, a priori, a construção de um referencial teórico sobre o conceito de segregação socioespacial, além de trazer alguns pontos importantes na luta pela reforma urbana no Brasil, como a aprovação do Estatuto da Cidade e a criação do Ministério das Cidades, para justificar as análises desses artigos a partir de tais marcos.

A utilização da meta-análise e do software Iramuteq se tornam importantes pois possibilitam reunir informações de vários estudos publicados no meio acadêmico sobre determinado conceito, gerando uma síntese dos resultados, que possibilita, dessa forma, revelar aspectos os quais há oportunidades e necessidade de estudos mais aprofundados.

\section{O CONCEITO DE SEGREGAÇÃO SOCIOESPACIAL}

O conceito de segregação socioespacial é utilizado por vários autores, em diferentes correntes, para explicar os processos advindos da urbanização em escala intra-urbana. Ao longo do século XX duas correntes principais se destacaram no que se refere a estudos sobre 0 
conceito. A primeira, que se inicia entre as décadas de 30 e 40, com análises produzidas por pesquisadores da Escola de Chicago. Já a segunda, de caráter marxista, ganha força a partir das décadas de 60 e 70, principalmente com pesquisadores franceses.

De acordo com a corrente de pensamento da Escola de Chicago, a segregação é considerada uma característica presente em todas as cidades. Esses pesquisadores se voltaram à observação da paisagem urbana, buscando assim perceber se de fato a segregação socioespacial se confirmava a partir da localização das diferentes classes sociais em lugares específicos e afastados. Acreditam, dessa forma, que a segregação é resultado de um processo de preferências individuais de cada um que lá vive. Assim sendo, para essa corrente, a segregação é um fato natural, comum e inerente do processo de urbanização, o que descarta, assim, a importância ou necessidade de se analisar e entender os atores, as causas e os fundamentos do processo (VIEIRA e MELAZZO, 2012).

Vários autores contribuíram com tais estudos. Um deles é Georg Simmel, teórico da sociologia formal, que exerceu grande influência na escola de Chicago. Simmel realizou seus estudos no início do século XX, descrevendo a respeito da vida mental metropolitana, onde aborda certos insights sociopsicológicos, trazendo considerações em torno da atitude de indiferença do típico habitante da metrópole moderna e seus determinantes. Em "As metrópoles e a vida mental" de 1903, o autor aponta a relação dual entre metrópole e vida mental, abordando a essência da metrópole na intensificação da vida nervosa dos indivíduos (VELHO, 1987 e LUZ, 2013).

Outro autor, Robert E. Park, considerado um dos grandes influenciadores da escola de Chigago, apresenta em seu artigo "A Cidade: sugestões para a investigação do comportamento humano", publicado em 1916 e considerado seu trabalho mais significativo, uma espécie de manifesto ou roteiro de estudos que orientou seus próprios trabalhos futuros, bem como os de outros autores, como Ernest Burgess e Roderick McKenzie. Assim, nessa obra, o autor estuda a cidade como um "organismo social", algumas vezes se colocando em nível estritamente ecológico, e em outras vezes entrando pelo campo mais propriamente sociológico. Esse autor exerceu, e ainda exerce, grandes influências sobre os estudos urbanos nos Estados Unidos (VELHO, 1987 e LUZ, 2013).

Há também a literatura de Louis Wirth, considerado o maior teórico de estudos urbanos norte-americanos e "sociólogo urbano" por excelência. O autor utilizou do urbano como categoria explicativa por si só. Wirth (em "O Urbanismo como modo de vida", publicado em 1938) afirma que o ponto principal de nossa sociedade moderna está no crescimento das cidades e que elas abarcam as várias formas de associações humanas, além de serem o local onde os vários grupos convivem com suas diferenças no mesmo espaço (VELHO, 1987 e LUZ, 2013).

A corrente marxista, por sua vez, diz que a segregação socioespacial é a reprodução no território da divisão social do trabalho, e percebe, assim, a relação do Estado no ordenamento do espaço urbano juntamente aos grupos hegemônicos e dominantes do capital que acabam influenciando na manutenção de uma dispersão controlada da classe trabalhadora. Dessa forma, há a reprodução das relações sociais que criam um vínculo paradoxal entre centro e periferia no espaço intra-urbano (SCHAEFFER, 2003).

Dentro dessa perspectiva da corrente marxista, alguns autores dão destaque maior a diferentes aspectos. Alguns focam na ideia de que o processo de segregação é resultado de uma luta ou disputa por localizações (o espaço urbano como mercadoria), a qual se dá, no entanto, entre grupos sociais ou entre classes (CASTELLS, 1983; VILLAÇA, 2001, 2011; MARICATO, 1997, 
2000; LEFEBVRE, 1999, 2002; GUIMARÃES, 2015; BONDUKI, 1998, 2010). Como resultado, distintas classes ou camadas sociais tendem a se concentrar cada vez mais em diferentes regiões ou conjunto de bairros da metrópole (VILLAÇA, 2001). Dessa forma, a localização da moradia (em relação ao centro) se torna um indicador importante, uma vez que envolve o deslocamento de pessoas ou produtos entre locais de moradias (periferia) e os de produção e consumo (centro), ou seja, a segregação existe na forma de separação social (VILLAÇA, 1998, 2001; CALDEIRA, 2000). Lago (2002) e Maricato (1997, 2000 e 2013), de maneira complementar, falam que a segregação, além de separação, também significa desigualdade de acesso.

Para Sposito (2016) a segregação socioespacial se revela quando as formas de diferenciação causam uma separação espacial radical e implicam na quebra, sempre relativa, da região segregada em relação ao conjunto do espaço urbano, gerando consequentemente uma dificuldade nas relações e nas articulações que movem a vida na cidade.

No Brasil, o mais conhecido padrão de segregação é o do centro versus periferia (CALDEIRA, 2000), onde o centro apresenta acesso a serviços urbanos, sejam públicos ou privados, ocupados pelas camadas de mais alta renda, e a periferia, ao contrário, subequipada e longínqua, ocupada pelas camadas de mais baixa renda (VILLAÇA, 2001), criando uma dualidade entre cidade dos ricos e cidade dos pobres, ou mesmo entre cidade legal e cidade ilegal (BONDUKI, 2010). Dessa maneira, a segregação socioespacial se tornou uma marca forte na consolidação das periferias, em comparação as melhores e maiores condições das camadas altas e médias da sociedade nas disputas por prioridades estatais e por recursos públicos. Tal ausência nas periferias foi contínua na urbanização periférica, isto é, desenvolveu-se uma estrutura precária, com insuficientes equipamentos sociais, déficit de infraestrutura e melhorias urbanas essenciais, como resultado da ocupação desordenada e ilegal, que compromete a qualidade de vida, a mobilidade, acesso a serviços e também ao mercado de trabalho (HUGHES, 2004).

Lojkine (1981), por sua vez, diz que a segregação socioespacial é uma manifestação da renda fundiária, onde a classe de mais alta renda acaba ficando com as terras de mais alto valor e as pessoas de mais baixa renda, ao contrário, com as terras de menor valor. Contudo, esse aspecto já foi refutado por vários trabalhos empíricos. Um desses trabalhos é o de autoria de Alonso (1965), que se refere as cidades dos Estados Unidos da América. No Brasil, de acordo com Villaça (2001), nem sempre as camadas mais ricas ocupam as terras mais caras (de maior preço por metro quadrado), mesmo que isso ocorra na maioria das vezes. Não obstante, a classe de mais alta renda também ocupa terras de baixo valor nas periferias de nossas cidades.

Por outro lado, e ainda segundo Villaça (2001), outros autores como Vetter e Massena (1981) e Pinçon-Charlot (1986) dão destaque ao aspecto da pressão de poderes políticos e econômicos sobre o Estado, que acabam agenciando distribuição desigual dos investimentos em infraestrutura.

Corroborando com esse aspecto, Castells (1978) aponta a importância da política no processo de segregação. Em outras palavras, o autor revela como a atuação e o papel exercido pelas diferentes forças e atores políticos e ideológicos estão presentes e atuantes na organização e produção do espaço urbano na sociedade capitalista. Ainda relata que uma dessas forças, ou atores políticos, é o próprio Estado, que acaba contribuindo com o processo de segregação na medida que é responsável pela formulação e implementação das suas políticas públicas, em destaque as habitacionais (Castells, 1978; Lojkine, 1981), na formulação de legislações urbanística, na fiscalização, e nos processos de planejamento e gestão da cidade. 
A segunda força, ou ator político, são os detentores do capital, que atuam promovendo as distribuições desiguais com toda sua representatividade junto as autoridades e seu poder de barganha e lóbi, além do uso de mecanismos de cooptação e controle, utilizando-se da imprensa, para manipular as classes média e baixa.

A terceira força, ou ator político, segundo Castells (1978), que influencia no processo de segregação socioespacial, são as próprias classes sociais menos favorecidas, devido ao seu limitado acesso às informações, sua falta de representatividade em espaços de discussão e participação ou mesmo por seu próprio desinteresse. Em síntese, concordando com Castells (1978), Lojkine (1981) diz que a organização espacial urbana é resultado da divisão social do trabalho, com uma ação fundamental do Estado que, para o autor, é apropriado pela classe dominante para realização de seus interesses em detrimento da sociedade em geral.

Em suma, segundo Vieira e Melazzo (2012), os autores desta corrente percebem o processo de segregação socioespacial como efeito das desigualdades existentes nas relações sociais entre as diferentes classes sociais, resultando no acesso desigual à cidade, seja pela sua localização espacial ou pelo acesso aos bens de consumo coletivos.

\section{ESTATUTO DA CIDADE E MINISTÉRIO DAS CIDADES}

De acordo com Maricato (1997), buscando diminuir o abismo que separa os espaços reservados aos ricos e aos pobres em nossas cidades, surge no Brasil uma luta pela chamada "reforma urbana" que culminou com dois momentos importantes nessa luta. O primeiro foi a aprovação do Estatuto da Cidade, Lei Federal 10.257/2001, que regulamentou o capítulo de política urbana da Constituição Federal Brasileira de 1988, ampliando os poderes dos municípios para legislar sobre seus territórios ao disponibilizar novos instrumentos de regulação e ordenamento urbanístico. O segundo momento, foi a criação do Ministério das Cidades, em 1 de janeiro de 2003, por meio da medida provisória no 103/2003, que foi convertida na Lei no 10.683 de 28 de maio de 2003.

Constituem áreas de competência do Ministério das Cidades: a) política de desenvolvimento urbano; b) políticas setoriais de habitação, saneamento ambiental, transporte urbano e trânsito; c) promoção, em articulação com as diversas esferas de governo, com o setor privado e organizações não-governamentais, de ações e programas de urbanização, de habitação, de saneamento básico e ambiental, transporte urbano, trânsito e desenvolvimento urbano; d) política de subsídio à habitação popular, saneamento e transporte urbano; e) planejamento, regulação, normatização e gestão da aplicação de recursos em políticas de desenvolvimento urbano, urbanização, habitação, saneamento básico e ambiental, transporte urbano e trânsito; f) participação na formulação das diretrizes gerais para conservação dos sistemas urbanos de água, bem como para a adoção de bacias hidrográficas como unidades básicas do planejamento e gestão do saneamento (MINISTÉRIO DAS CIDADES, 2017).

A luta pela "reforma urbana" iniciada no Brasil ainda nos anos 70 teve como uma de suas vitórias mais expressivas a apresentação de uma emenda de iniciativa popular à Constituição Federal de 1988, além de ter conquistado a inclusão na Carta Magna da função social da propriedade e a função social da cidade. Outra vitória muito importante só veio a acontecer 13 anos depois, com a aprovação da Lei 10.257/2001, chamada de Estatuto da Cidade.

Ao mesmo tempo, ao longo dessa luta social, em várias ocasiões foi formulada uma proposta de criação de uma instância federal que fosse voltada para as políticas urbanas. 
Contudo, somente no Projeto Moradia, divulgado em 2000, que houve uma formulação mais clara do Ministério das Cidades. Em outras palavras, o Ministério das Cidades tem sua criação ligada ao movimento social urbano que se iniciou nos anos 70 e que foi acumulando forças nas décadas de 80 e 90 com a luta pela democratização do país e pela reforma urbana (MARICATO, 2006).

\section{PROCEDIMENTO METODOLÓGICO}

Buscando responder ao objetivo proposto, que se resume em realizar uma síntese do que está sendo discutido na academia a respeito da temática "segregação socioespacial", optou-se por utilizar a meta-análise como operacionalizador desse trabalho. Luiz (2002) diz ser uma técnica que permite obter informações adicionais de dados já existentes, ou seja, por meio da análise conjunta de dados de vários trabalhos e aplicação de uma ou mais técnicas estatísticas é possível extrair tais informações, e assim, permitir fazer uma associação dos novos resultados, gerando uma síntese ou uma nova conclusão.

A vantagem desse método se revela uma vez que permite uma avaliação crítica dos resultados dos trabalhos analisados, possibilitando assim, embasamento para uma discussão sobre as semelhanças e diferenças que podem existir entre os resultados. Ademais, pode revelar questionamentos não propostos anteriormente, permitindo assim, proposições de novos trabalhos acerca da temática.

Assim sendo, para desenvolvimento dessa pesquisa, foram analisadas todas as publicações que continham em seus títulos o termo "segregação socioespacial" no período de 2001 a 2017. A opção desse recorte temporal se deu devido ao marco da promulgação do Estatuto da Cidade em 2001, visto que as principais competências desses trabalhos contemplavam a política de desenvolvimento urbano, políticas setoriais de habitação, saneamento ambiental, transporte urbano e trânsito.

Durante a análise dos artigos objetivou-se gerar uma síntese a respeito de seus focos principais, objetivos dos trabalhos, anos de publicação, periódico o qual está vinculado e as metodologias utilizadas para realização dos trabalhos.

Para seleção dos trabalhos que foram analisados, utilizou-se os filtros: Portal de Periódicos da CAPES, Google Acadêmico e SciELO entre os dias 7 de agosto de 2017 a 18 de agosto de 2017. Durante o processo de seleção dos trabalhos, optou-se por buscar todos artigos que tivessem em seus títulos o termo "segregação socioespacial", o que gerou um número muito grande de achados. Contudo, excluiu-se todos aqueles que não fossem publicações em periódicos, ou seja, aqueles que eram dissertações de mestrado, teses de doutorado e publicações em anais de eventos. Após todo esse crivo, 36 artigos se adaptaram ao objetivo da pesquisa e permitiu-se, assim, realizar as análises do presente trabalho.

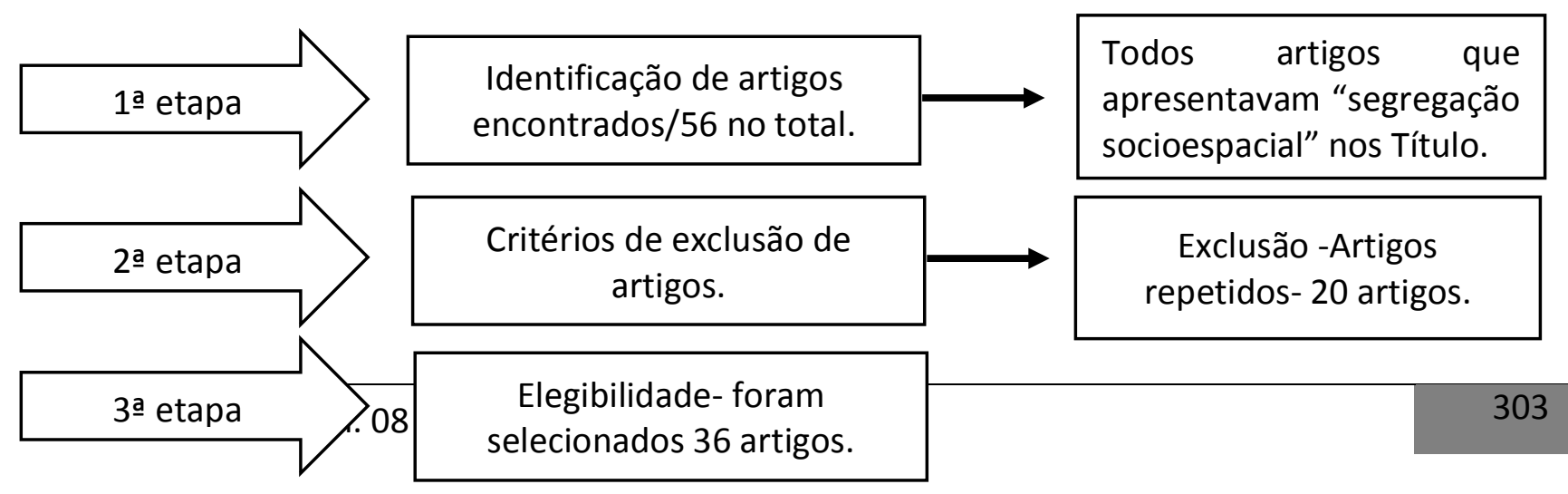


Figura 1- Esquema das etapas do processo de seleção dos artigos Fonte: Elaboração própria a partir de dados da pesquisa, 2017.

O Portal de Periódicos da CAPES, é uma biblioteca virtual que reúne e disponibiliza a instituições de ensino e pesquisa no Brasil o melhor da produção científica internacional. A sigla, CAPES, significa Coordenação de Aperfeiçoamento de pessoal de Nível Superior e é uma fundação veiculada ao Ministério da Educação (MEC) do Brasil. O portal conta com um acervo de mais de 38 mil títulos com texto completo, 134 bases referenciais, 11 bases dedicadas exclusivamente a patentes, além de livros, enciclopédias e obras de referência, normas técnicas, estatísticas e conteúdo audiovisual (PORTAL DE PERIÓDICOS DA CAPES, 2017).

Já a Scientific Electronic Library Online - SciELO - é uma biblioteca eletrônica que abarca uma seleção de periódicos científicos e é resultado de um projeto de pesquisa da FAPESP Fundação de Amparo à Pesquisa de São Paulo - em parceria com a Bireme - Centro LatinoAmericano e do Caribe de Informação em Ciências da Saúde - e com o apoio do CNPq - Conselho Nacional de Desenvolvimento Científico e Tecnológico. Atualmente o banco de dados da SciELO conta com 1.256 periódicos ativos (SCIELO, 2017).

Por sua vez, o Google Acadêmico classifica os resultados de pesquisa segundo a relevância no mundo acadêmico. De maneira similar à da pesquisa web da Google, as referências mais relevantes são exibidas no começo da página. A tecnologia de classificação da Google leva em conta o texto integral de cada artigo, o autor, a publicação em que o artigo saiu e a frequência com que foi citado em outras publicações acadêmicas (GOOGLE, 2017).

A metodologia foi dividida em duas etapas: a primeira foi a leitura dos trabalhos selecionados para a geração dos dados utilizados na primeira parte das discussões que se seguem; a segunda etapa foi agrupar em um único documento (chamado de corpus) todos os resumos e introduções para uma análise textual, no software Iramuteq 0.7 Alpha 2. Tal agrupamento possibilitou a identificação das palavras mais recorrentes e associadas entre sim, gerando clusters de palavras mais associadas no que diz respeito à discussão sobre o conceito de "segregação socioespacial".

\section{RESULTADOS E DISCUSSÕES}

A partir da busca feita nos filtros referenciados na metodologia desse trabalho, foram localizados 36 artigos que traziam "segregação socioespacial" em seus títulos. Visando facilitar a disposição dos dados, cada um dos artigos recebeu um código que variou de Art 1 a Art 36, em ordem crescente dos números. O Quadro 1, a seguir, mostra os resultados encontrados na busca, no que tange a: seus títulos, ano de publicação, percurso metodológico utilizadas nos trabalhos e primeiro autor.

Quadro 1- Informações preliminares sobre os artigos analisados 


\begin{tabular}{|c|c|c|c|c|}
\hline Artigos & Título & Ano & Percurso metodológico $^{1}$ & $\begin{array}{l}\text { Primeiro } \\
\text { Autor }\end{array}$ \\
\hline Art 1 & $\begin{array}{l}\text { Rudimentos para o exame da } \\
\text { urbanização em sua fase crítica: } \\
\text { uma aproximação ao conceito de } \\
\text { segregação socioespacial }\end{array}$ & 2001 & $\begin{array}{l}\text { Pesquisa Bibliográfica/ Ensaio } \\
\text { teórico }\end{array}$ & $\begin{array}{l}\text { Maurício } \\
\text { Sogame }\end{array}$ \\
\hline Art 2 & $\begin{array}{l}\text { Nos limites do viver: moradia e } \\
\text { segregação socioespacial nas } \\
\text { áreas metropolitanas do } \\
\text { Nordeste brasileiro }\end{array}$ & 2003 & $\begin{array}{l}\text { Pesquisa Bibliográfica/ Estudo de } \\
\text { caso (Nordeste brasileiro) }\end{array}$ & $\begin{array}{l}\text { Anelino } \\
\text { Francisco } \\
\text { da Silva }\end{array}$ \\
\hline Art 3 & $\begin{array}{l}\text { Introdução ao conceito de } \\
\text { segregação socioespacial }\end{array}$ & 2003 & $\begin{array}{l}\text { Pesquisa Bibliográfica/ Ensaio } \\
\text { teórico }\end{array}$ & $\begin{array}{l}\text { Alexandre } \\
\text { Bergamin } \\
\text { Vieira }\end{array}$ \\
\hline Art 4 & $\begin{array}{l}\text { Segregação socioespacial no } \\
\text { Distrito Federal }\end{array}$ & 2003 & $\begin{array}{l}\text { Pesquisa Bibliográfica e Pesquisa } \\
\text { Documental/ Estudo de caso } \\
\text { (Brasília-DF) }\end{array}$ & $\begin{array}{l}\text { Maria de } \\
\text { Fátima } \\
\text { Castilhos } \\
\text { Schaeffer }\end{array}$ \\
\hline Art 5 & $\begin{array}{l}\text { Segregação socioespacial e } \\
\text { violência na cidade de São Paulo - } \\
\text { Referências para a formulação de } \\
\text { políticas públicas }\end{array}$ & 2004 & $\begin{array}{l}\text { Pesquisa Bibliográfica e Pesquisa } \\
\text { Documental/ Estudo de caso (São } \\
\text { Paulo) }\end{array}$ & $\begin{array}{l}\text { Pedro } \\
\text { Javier } \\
\text { Aguerre } \\
\text { Hughes }\end{array}$ \\
\hline Art 6 & $\begin{array}{l}\text { Polarização e segregação } \\
\text { socioespacial em uma metrópole } \\
\text { periférica }\end{array}$ & 2004 & $\begin{array}{l}\text { Pesquisa Bibliográfica e Pesquisa } \\
\text { Documental/ Estudo de caso } \\
\text { (Salvador-BA) }\end{array}$ & $\begin{array}{l}\text { Inaiá Maria } \\
\text { Moreira de } \\
\text { Carvalho }\end{array}$ \\
\hline Art 7 & $\begin{array}{llr}\text { Estruturação } & \text { intra-urbana } & \text { na } \\
\text { região do Distrito Federal e } \\
\text { entorno: a mobilidade e a } \\
\text { segregação } \\
\text { população }\end{array}$ & 2005 & $\begin{array}{l}\text { Pesquisa Bibliográfica e Pesquisa } \\
\text { Documental/ Estudo de caso } \\
\text { (Distrito Federal e entorno) }\end{array}$ & $\begin{array}{l}\text { Maria Célia } \\
\text { Silva } \\
\text { Caiado }\end{array}$ \\
\hline Art 8 & $\begin{array}{l}\text { Segregação socioespacial em } \\
\text { Belo Horizonte: uma aplicação de } \\
\text { modelos difusos }\end{array}$ & 2005 & $\begin{array}{l}\text { Pesquisa Bibliografica e Pesquisa } \\
\text { Documental/ FANNY - Fuzzy } \\
\text { Analysis } \\
\text { (Belo Horizonte-MG) }\end{array}$ & $\begin{array}{l}\text { Adriana } \\
\text { Miranda- } \\
\text { Ribeiro }\end{array}$ \\
\hline Art 9 & $\begin{array}{l}\text { Dinâmica metropolitana e } \\
\text { segregação sócioespacial }\end{array}$ & 2007 & $\begin{array}{l}\text { Pesquisa Bibliográfica e Pesquisa } \\
\text { Documental/ Estudo de caso } \\
\text { (Salvador-BA) }\end{array}$ & $\begin{array}{l}\text { Inaiá Maria } \\
\text { Moreira de } \\
\text { Carvalho }\end{array}$ \\
\hline Art 10 & $\begin{array}{l}\text { Reestruturação urbana } \\
\text { segregação socioespacial no } \\
\text { interior paulista }\end{array}$ & 2007 & $\begin{array}{l}\text { Pesquisa Bibliográfica e Pesquisa } \\
\text { Documental/ Estudo de caso (São } \\
\text { Paulo) }\end{array}$ & $\begin{array}{l}\text { Maria } \\
\text { Encarnação } \\
\text { Beltrão } \\
\text { Sposito }\end{array}$ \\
\hline Art 11 & $\begin{array}{l}\text { Segregação socioespacial em } \\
\text { cidades médias: diferenças ou } \\
\text { semelhanças? Um estudo sobre o } \\
\text { jardim cinquentário e o jardim } \\
\text { morada do sol em presidente } \\
\text { prudente-SP }\end{array}$ & 2007 & $\begin{array}{l}\text { Pesquisa Bibliográfica e pesquisa } \\
\text { documental/ Análise comparativa } \\
\text { (Presidente Prudente-SP) }\end{array}$ & $\begin{array}{c}\text { Adauto } \\
\text { Rodrigues } \\
\text { de Almeida } \\
\text { Júnior }\end{array}$ \\
\hline Art 12 & $\begin{array}{l}\text { Segregação } \quad \text { socioespacial } \\
\text { interurbana: uma hipótese? }\end{array}$ & 2008 & $\begin{array}{l}\text { Pesquisa Bibliográfica e pesquisa } \\
\text { documental/ }\end{array}$ & $\begin{array}{l}\text { Cláudia } \\
\text { Marques }\end{array}$ \\
\hline
\end{tabular}

\footnotetext{
${ }^{1} \mathrm{O}$ "percurso metodológico" foi elaborado com base na percepção dos autores desse artigo, uma vez que grande parte dos trabalhos analisados não deixavam explícitos o caminho metodológico adotado.
} 


\begin{tabular}{|c|c|c|c|c|}
\hline & & & Estudo de caso (Mariápolis-SP) & Roma \\
\hline Art 13 & \begin{tabular}{l}
\multicolumn{2}{l}{ Segregação } & \multicolumn{2}{c}{ socioespacial, } \\
dinâmica populacional e rede \\
urbana na cidade \\
Parintins/AM
\end{tabular} & 2009 & $\begin{array}{l}\text { Pesquisa Bibliográfica e pesquisa } \\
\text { documental/ } \\
\text { Estudo de caso (Parintins-AM) }\end{array}$ & $\begin{array}{l}\text { Thiago } \\
\text { Pimentel } \\
\text { Marinho }\end{array}$ \\
\hline Art 14 & $\begin{array}{l}\text { A segregação sócio espacial } \\
\text { urbana em Presidente Prudente- } \\
\text { SP }\end{array}$ & 2009 & $\begin{array}{l}\text { Pesquisa Bibliográfica e pesquisa } \\
\text { documental/ Análise comparativa } \\
\text { (Presidente Prudente-SP) }\end{array}$ & $\begin{array}{c}\text { Rones } \\
\text { Borges } \\
\text { Silva } \\
\end{array}$ \\
\hline Art 15 & \begin{tabular}{ll} 
Segregação & \multicolumn{2}{c}{ socioespacial: } \\
contradições & presentes em \\
Palmas/TO &
\end{tabular} & 2009 & $\begin{array}{l}\text { Pesquisa Bibliográfica e pesquisa } \\
\text { documental/ Análise comparativa } \\
\text { (Palmas-TO) }\end{array}$ & $\begin{array}{l}\text { Jonathas } \\
\text { Magalhães } \\
\text { Pereira da } \\
\text { Silva }\end{array}$ \\
\hline Art 16 & $\begin{array}{l}\text { Segregação socioespacial e ações } \\
\text { do plano diretor no bairro Maria } \\
\text { Eugênia e a área central de } \\
\text { viçosa, MG }\end{array}$ & 2010 & $\begin{array}{l}\text { Pesquisa Bibliográfica e pesquisa } \\
\text { documental/ Análise comparativa } \\
\text { (Viçosa-MG), SIG e Excel }\end{array}$ & $\begin{array}{l}\text { Nádia } \\
\text { Menezes } \\
\text { de } \\
\text { Rodrigues }\end{array}$ \\
\hline Art 17 & $\begin{array}{l}\text { Segregação socioespacial e } \\
\text { inserção no mercado de trabalho } \\
\text { na Região Metropolitana de } \\
\text { Campinas }\end{array}$ & 2010 & $\begin{array}{l}\text { Pesquisa Bibliográfica e pesquisa } \\
\text { documental/ Índice de Moran } \\
\text { local }\end{array}$ & $\begin{array}{l}\text { José } \\
\text { Marcos } \\
\text { Pinto da } \\
\text { Cunha }\end{array}$ \\
\hline Art 18 & $\begin{array}{l}\text { O direito da criança e do } \\
\text { adolescente à convivência } \\
\text { comunitária: o ministério das } \\
\text { cidades na institucionalização das } \\
\text { políticas de combate à } \\
\text { segregação socioespacial urbana }\end{array}$ & 2010 & $\begin{array}{l}\text { Pesquisa Bibliográfica e Ensaio } \\
\text { Teórico }\end{array}$ & $\begin{array}{l}\text { Benedicto } \\
\quad \text { de } \\
\text { Vasconcell } \\
\text { os Luna } \\
\text { Gonçalves } \\
\text { Patrão }\end{array}$ \\
\hline Art 19 & $\begin{array}{lcr}\text { Homicídios } & \text { de jovens } & \text { e } \\
\text { segregação } & \text { socioespacial } & \text { em } \\
\text { Londrina } & & \end{array}$ & 2011 & $\begin{array}{l}\text { Pesquisa Bibliográfica e pesquisa } \\
\text { documental/ Estudo de caso e } \\
\text { Análise qualitativa (Londrina-PR) }\end{array}$ & Dione Lolis \\
\hline Art 20 & $\begin{array}{l}\text { A segregação socioespacial na } \\
\text { metrópole paulista }\end{array}$ & 2011 & $\begin{array}{l}\text { Pesquisa Bibliográfica e pesquisa } \\
\text { documental/ Estudo de caso (São } \\
\text { Paulo-SP) }\end{array}$ & $\begin{array}{c}\text { Glória da } \\
\text { Anunciação } \\
\text { Alves }\end{array}$ \\
\hline Art 21 & $\begin{array}{l}\text { Urbanização, habitação } \\
\text { segregação socioespacial }\end{array}$ & 2012 & $\begin{array}{l}\text { Pesquisa Bibliográfica e pesquisa } \\
\text { documental/ Estudo de caso (São } \\
\text { José dos Campos-SP) }\end{array}$ & $\begin{array}{l}\text { Andrea Lise } \\
\text { Campos } \\
\text { Suriano }\end{array}$ \\
\hline Art 22 & $\begin{array}{l}\text { Segregação } \\
\text { constituição do sujeito e e } \\
\text { significação do cotidiano }\end{array}$ & 2012 & $\begin{array}{l}\text { Pesquisa Bibliográfica/ Análises o } \\
\text { par eu-outro e Estudo de caso }\end{array}$ & $\begin{array}{c}\text { Elton } \\
\text { André Silva } \\
\text { de Castro }\end{array}$ \\
\hline Art 23 & $\begin{array}{l}\text { Segregação socioespacial e o } \\
\text { direito à natureza urbana na } \\
\text { cidade de Manaus }\end{array}$ & 2012 & $\begin{array}{l}\text { Pesquisa Bibliográfica e pesquisa } \\
\text { documental/ Estudo de caso } \\
\text { (Manaus-AM) }\end{array}$ & $\begin{array}{c}\text { Estevan } \\
\text { Bartoli }\end{array}$ \\
\hline Art 24 & $\begin{array}{l}\text { Planejamento urbano } \\
\text { segregação socioespacial na } \\
\text { cidade de Macapá }\end{array}$ & 2013 & $\begin{array}{l}\text { Pesquisa Bibliográfica e pesquisa } \\
\text { documental/ Estudo de caso } \\
\text { (Macapá-AP) }\end{array}$ & $\begin{array}{l}\text { Raimundo } \\
\text { Gomes } \\
\text { Barbosa }\end{array}$ \\
\hline Art 25 & $\begin{array}{l}\text { Conexões } \quad \text { geográficas } \text { e } \\
\text { segregação socioespacial pelo } \\
\text { uso das prisões no estado de São } \\
\text { Paulo }\end{array}$ & 2013 & $\begin{array}{l}\text { Pesquisa Bibliográfica e pesquisa } \\
\text { documental, dados empíricos, } \\
\text { cartografia. }\end{array}$ & $\begin{array}{c}\text { James } \\
\text { Humberto } \\
\text { Zomighani } \\
\text { Jr. }\end{array}$ \\
\hline Art 26 & $\begin{array}{l}\text { Projeto PAC "Contorno Norte" de } \\
\text { Maringá: os impactos da obra e o } \\
\text { aprofundamento do processo de }\end{array}$ & 2014 & $\begin{array}{l}\text { Pesquisa Bibliográfica e } \\
\text { documental/ Aplicação de Survey }\end{array}$ & $\begin{array}{l}\text { Felipe } \\
\text { Fontana }\end{array}$ \\
\hline
\end{tabular}




\begin{tabular}{|c|c|c|c|c|}
\hline & $\begin{array}{l}\text { segregação socioespacial na } \\
\text { Região Metropolitana de Maringá }\end{array}$ & & & \\
\hline Art 27 & $\begin{array}{l}\text { Turismo urbano e a segregação } \\
\text { socioespacial: } \\
\text { problemáticas }\end{array}$ & 2014 & Revisão Bibliográfica & $\begin{array}{l}\text { Luiz } \\
\text { Fernando } \\
\text { Roscoche }\end{array}$ \\
\hline Art 28 & $\begin{array}{l}\text { Segregação socioespacial e luta } \\
\text { por moradia na Grande } \\
\text { Florianópolis: raízes es e } \\
\text { características da Ocupação } \\
\text { Contestado }\end{array}$ & 2015 & $\begin{array}{l}\text { Pesquisa Bibliográfica e pesquisa } \\
\text { de campo }\end{array}$ & $\begin{array}{l}\text { Luís Felipe } \\
\quad \text { Aires } \\
\text { Magalhães }\end{array}$ \\
\hline Art 29 & $\begin{array}{l}\text { Segregação socioespacial na } \\
\text { região metropolitana de Belo } \\
\text { Horizonte: o estigma de Ribeirão } \\
\text { das Neves/MG }\end{array}$ & 2015 & $\begin{array}{l}\text { Pesquisa Bibliográfica e e } \\
\text { documental/ Análise sistemática }\end{array}$ & $\begin{array}{l}\text { Osmar } \\
\text { Henrique } \\
\text { Ribeiro da } \\
\text { Silva }\end{array}$ \\
\hline Art 30 & $\begin{array}{l}\text { Dentro e fora dos muros: } \\
\text { residenciais fechados } \\
\text { segregação socioespacial em } \\
\text { cidades não metropolitanas }\end{array}$ & 2015 & $\begin{array}{l}\text { Pesquisa Bibliográfica, } \\
\text { entrevistas/ Análise comparativa }\end{array}$ & $\begin{array}{l}\text { Patrícia } \\
\text { Helena } \\
\text { Milani }\end{array}$ \\
\hline Art 31 & $\begin{array}{l}\text { Segregação socioespacial na } \\
\text { urbe carioca: o exemplo de } \\
\text { Campo Grande-RJ }\end{array}$ & 2015 & $\begin{array}{l}\text { Pesquisa Bibliográfica e pesquisa } \\
\text { documental/Análise regressiva- } \\
\text { progressiva e análise comparativa }\end{array}$ & $\begin{array}{l}\text { Vânia } \\
\text { Regina } \\
\text { Jorge da } \\
\text { Silva }\end{array}$ \\
\hline Art 32 & $\begin{array}{l}\text { Segregação socioespacial: os } \\
\text { impactos das desigualdades } \\
\text { sociais frente a formação e } \\
\text { ocupação do espaço urbano. }\end{array}$ & 2016 & $\begin{array}{l}\text { Pesquisa Bibliográfica e pesquisa } \\
\text { documental/ Estudo de caso (Pau } \\
\text { dos Ferros-RN) }\end{array}$ & $\begin{array}{l}\text { Manoel } \\
\text { Mariano } \\
\text { Neto da } \\
\text { Silva }\end{array}$ \\
\hline Art 33 & $\begin{array}{l}\text { Segregação socioespacial e } \\
\text { política urbana em cidades } \\
\text { médias no brasil contemporâneo } \\
(2001-2011)\end{array}$ & 2016 & $\begin{array}{l}\text { Pesquisa Bibliográfica e pesquisa } \\
\text { documental/ Análise comparativa }\end{array}$ & $\begin{array}{l}\text { Jefferson } \\
\text { O. Goulart }\end{array}$ \\
\hline Art 34 & $\begin{array}{l}\text { Análise do clima urbano a partir } \\
\text { da segregação socioespacial e } \\
\text { socioambiental em presidente } \\
\text { prudente, SP, Brasil }\end{array}$ & 2016 & $\begin{array}{l}\text { Pesquisa Bibliográfica e pesquisa } \\
\text { documental/ Estudo de caso } \\
\text { (Presidente Prudente-SP) }\end{array}$ & $\begin{array}{l}\text { Renata dos } \\
\text { Santos } \\
\text { Cardoso }\end{array}$ \\
\hline Art 35 & $\begin{array}{l}\text { Urbanização e Segregação } \\
\text { Socioespacial: O Papel do Estado } \\
\text { no Planejamento Urbano }\end{array}$ & 2016 & Pesquisa Bibliográfica & $\begin{array}{l}\text { Maria dos } \\
\text { Remédios } \\
\text { Beserra }\end{array}$ \\
\hline Art 36 & $\begin{array}{l}\text { A disputa pelo lixo e a resistência } \\
\text { dos catadores em contextos de } \\
\text { segregação socioespacial }\end{array}$ & 2017 & $\begin{array}{l}\text { Pesquisa Bibliográfica e pesquisa } \\
\text { documental/ Estudo de caso } \\
\text { (Campos dos Goytacazes-RJ) }\end{array}$ & $\begin{array}{l}\text { Érica } \\
\text { Terezinha } \\
\text { Vieira de } \\
\text { Almeida }\end{array}$ \\
\hline
\end{tabular}

Fonte: Elaboração própria com base em dados da pesquisa (2017)

Após a exposição do quadro 1 , referente aos trabalhos encontrados para análise, os resultados foram divididos em 6 subitens, que correspondem as categorias de análise desse trabalho. São eles: Percursos metodológicos, autores dos trabalhos, análises das publicações, periódicos que veiculam os trabalhos e seus respectivos Qualis capes, autores mais utilizados como referências bibliográficas e por fim, análise do Corpus a partir do programa Iramuteq (Clusters e Fatorial) 


\subsection{Percursos metodológicos}

Quando analisados os percursos metodológicos utilizados nos artigos selecionados, percebe-se que a pesquisa bibliográfica é recorrente em todos os trabalhos. Tal afirmação se torna evidente por esse elemento ser fundamental para criação do referencial teórico que vai embasar as discussões dos trabalhos. A pesquisa documental (reunião de documentos para geração de informações, dados, tabelas e mapas) está presente em 28 dos 36 artigos. Já no que se refere ao método, percebe-se que em 18 artigos utilizou-se do estudo de caso e em 7 artigos utilizou-se da análise comparativa para explicar o fenômeno. Ou seja, 25 dos 36 trabalhos buscam em realidades especificas, ou de forma comparativa, perceber ou aplicar o conceito para entender a realidade.

\subsection{Autores dos Trabalhos}

Dentre os autores dos trabalhos analisados, dois se destacam: Inaiá Maria Moreira de Carvalho e Maria Encarnação Beltrão Sposito. A primeira ganha relevância já que é a única que apresenta dois trabalhos publicados no período de análise. A segunda, Sposito (Quadro 3), se destaca, uma vez que, além de ser um dos autores dos trabalhos analisados, também é um dos autores mais referenciados pelos demais, ou seja, além de estar publicando trabalhos, é também referência para os outros pesquisadores.

\subsection{Análise das publicações}

Partindo nesse momento para uma análise das publicações ao longo do tempo, ou seja, buscando entender os anos que houveram maior número de publicações, expõem-se nesse momento os dados que indicam tal evolução. Percebe-se que apenas um artigo sobre a temática (em amarelo na figura 2) foi publicado antes da criação do Ministério das Cidades em 2003. Entretanto, coincide com a data de promulgação da lei que regulamenta o Estatuto da Cidade, que teve início antes mesmo da criação do Ministério das Cidades. Porém, a discussão sobre a temática "segregação socioespacial" se intensificou até o ano de 2016. Nota-se que os anos de 2015 e 2016 são os mais produtivos em termos de publicações - talvez pelas grandes mudanças estruturais que o país passou após as obras da copa do mundo de futebol em 2014 e olimpíadas do Rio em 2016 - e seus assuntos variaram desde discussões sobre ocupação, estigma, residenciais fechados, política urbana e clima urbano até o papel do estado no planejamento urbano. 


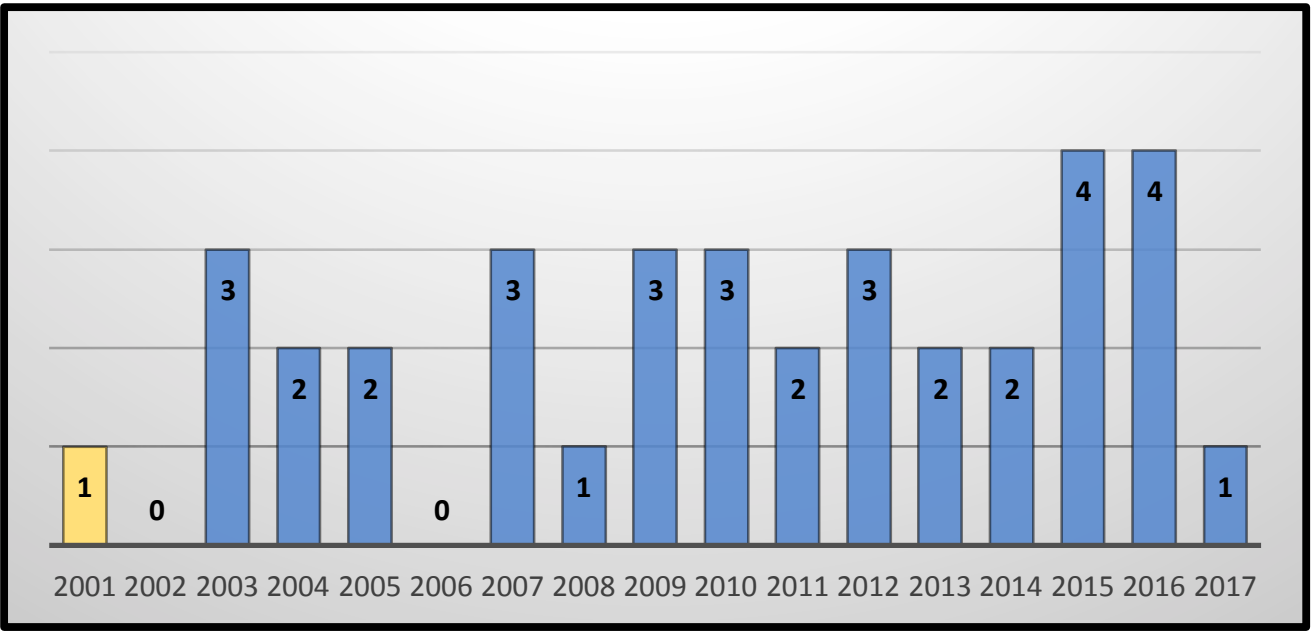

Figura 2 - Número de publicações por ano

Fonte: Elaborado pelo autor a partir de dados da pesquisa (2017)

Percebe-se também que, apenas 6 trabalhos abordaram o Estatuto da Cidade em seu conteúdo (Art 15, Art 16, Art 18, Art 23, Art 33 e Art 35) e 2 mencionam o Ministério das Cidades (Art 18 e Art 28) em suas discussões, revelando baixa associação entre o proposto pelo estatuto e atuação do ministério frente à questão da segregação socioespacial. Ou seja, as discussões não se estruturam em críticas sobre as mudanças esperadas nos municípios após promulgação do estatuto e criação do ministério, mas sim, em perceber os determinantes do fenômeno em cada caso estudado.

Diferente desses artigos de cunho mais empíricos, alguns artigos, por outro lado, se preocuparam em contribuir com uma discussão teórica, ou seja, além de não trazendo um caso especifico, se utilizaram de um diálogo entre vários autores para refletir sobre o entendimento do processo de segregação socioespacial em diferentes visões.

\subsection{Periódicos que veiculam os trabalhos e seus respectivos Qualis capes}

$\mathrm{Na}$ análise que se segue buscou-se ilustrar aqueles periódicos que estão veiculando os trabalhos aqui selecionados. Para tanto, o Quadro 2 revela os periódicos, a área de avaliação CAPES e seus respectivos Qualis. Sabe-se que a questão da segregação socioespacial é estudada de forma multidisciplinar, contudo, selecionou-se para análise aquelas áreas que julgamos serem as mais próximas da discussão.

Quadro 2: Informações sobre os periódicos e seus respectivos Qualis capes

\begin{tabular}{|c|c|c|c|}
\hline Artigos & Periódico & Área de avaliação capes & $\begin{array}{l}\text { Qualis } \\
\text { capes } \\
13-16\end{array}$ \\
\hline Art 1 & Geografares & $\begin{array}{l}\text { - Geografia } \\
\text { - Planejamento urbano e regional / demografia } \\
\text { - Arquitetura, urbanismo e design } \\
\text { - Administração pública e de empresas, ciências contábeis e } \\
\text { turismo } \\
\text { - Sociologia }\end{array}$ & $\begin{array}{l}\text { B2 } \\
\text { B3 } \\
\text { B3 } \\
\text { B3 } \\
\text { B5 }\end{array}$ \\
\hline
\end{tabular}




\begin{tabular}{|c|c|c|c|}
\hline Art 2 & $\begin{array}{l}\text { Revista } \\
\text { electrónica } \\
\text { de geografía } \\
\text { y ciencias } \\
\text { sociales }\end{array}$ & $\begin{array}{l}\text { - Planejamento urbano e regional / demografia } \\
\text { - Arquitetura, urbanismo e design } \\
\text { - Geografia } \\
\text { - Administração pública e de empresas, ciências contábeis e } \\
\text { turismo } \\
\text { - Sociologia }\end{array}$ & $\begin{array}{l}\text { A2 } \\
\text { A2 } \\
\text { A2 } \\
\text { B1 } \\
\text { B4 }\end{array}$ \\
\hline Art 3 & $\begin{array}{l}\text { Formação } \\
\text { (online) }\end{array}$ & $\begin{array}{l}\text { - Geografia } \\
\text { - Administração pública e de empresas, ciências contábeis e } \\
\text { turismo } \\
\text { - Sociologia }\end{array}$ & $\begin{array}{l}\text { B2 } \\
\text { B3 } \\
\text { B5 }\end{array}$ \\
\hline Art 4 & $\begin{array}{l}\text { Revista } \\
\text { Katálysis }\end{array}$ & $\begin{array}{l}\text { - Serviço social } \\
\text { - Arquitetura, urbanismo e design } \\
\text { - Planejamento urbano e regional / demografia } \\
\text { - Administração pública e de empresas, ciências contábeis e } \\
\text { turismo } \\
\text { - Sociologia } \\
\text { - Geografia }\end{array}$ & $\begin{array}{l}\text { A1 } \\
\text { A2 } \\
\text { B1 } \\
\text { B1 } \\
\text { B1 } \\
\text { B5 }\end{array}$ \\
\hline Art 5 & $\begin{array}{l}\text { São Paulo } \\
\text { em } \\
\text { Perspectiva }^{2}\end{array}$ & $\begin{array}{l}\text { - Planejamento urbano e regional / demografia } \\
\text { - Geografia } \\
\text { - Arquitetura, urbanismo e design } \\
\text { - Sociologia } \\
\text { - Serviço social }\end{array}$ & $\begin{array}{l}\text { B1 } \\
\text { B2 } \\
\text { B3 } \\
\text { B5 } \\
\text { C }\end{array}$ \\
\hline Art 6 & Caderno CRH & $\begin{array}{l}\text { - Sociologia } \\
\text { - Planejamento urbano e regional / demografia } \\
\text { - Arquitetura, urbanismo e design } \\
\text { - Serviço social } \\
\text { - Administração pública e de empresas, ciências contábeis e } \\
\text { turismo }\end{array}$ & $\begin{array}{l}\text { A1 } \\
\text { A2 } \\
\text { A2 } \\
\text { A2 } \\
\text { B1 }\end{array}$ \\
\hline Art 7 & $\begin{array}{l}\text { Revista } \\
\text { Brasileira de } \\
\text { Estudos de } \\
\text { População }\end{array}$ & $\begin{array}{l}\text { - Planejamento urbano e regional / demografia } \\
\text { - Sociologia } \\
\text { - Administração pública e de empresas, ciências contábeis e } \\
\text { turismo }\end{array}$ & $\begin{array}{l}\text { A2 } \\
\text { A2 } \\
\text { B1 }\end{array}$ \\
\hline Art 8 & $\begin{array}{c}\text { Revista } \\
\text { Geografias }\end{array}$ & $\begin{array}{l}\text { - Planejamento urbano e regional / demografia } \\
\text { - Geografia }\end{array}$ & $\begin{array}{l}\text { B2 } \\
\text { B2 }\end{array}$ \\
\hline Art 9 & Caderno CRH & $\begin{array}{l}\text { - Sociologia } \\
\text { - Planejamento urbano e regional / demografia } \\
\text { - Arquitetura, urbanismo e design } \\
\text { - Serviço social } \\
\text { - Administração pública e de empresas, ciências contábeis e } \\
\text { turismo }\end{array}$ & $\begin{array}{l}\text { A1 } \\
\text { A2 } \\
\text { A2 } \\
\text { A2 } \\
\text { B1 }\end{array}$ \\
\hline Art 10 & $\begin{array}{l}\text { Revista } \\
\text { electrónica } \\
\text { de geografía } \\
\text { y ciencias } \\
\text { sociales }\end{array}$ & $\begin{array}{l}\text { - Planejamento urbano e regional / demografia } \\
\text { - Arquitetura, urbanismo e design } \\
\text { - Geografia } \\
\text { - Administração pública e de empresas, ciências contábeis e } \\
\text { turismo } \\
\text { - Sociologia }\end{array}$ & $\begin{array}{l}\text { A2 } \\
\text { A2 } \\
\text { A2 } \\
\text { B1 } \\
\text { B4 }\end{array}$ \\
\hline Art 11 & $\begin{array}{l}\text { Geografia } \\
\text { em Atos }\end{array}$ & $\begin{array}{l}\text { - Geografia } \\
\text { - Administração pública e de empresas, ciências contábeis e } \\
\text { turismo }\end{array}$ & \begin{tabular}{|l} 
B3 \\
B4 \\
B5
\end{tabular} \\
\hline
\end{tabular}

${ }^{2}$ Avaliação Qualis capes triênio 2010-2012 


\begin{tabular}{|c|c|c|c|}
\hline & & - Arquitetura, urbanismo e design & \\
\hline Art 12 & Terra Livre & - Geografia & B1 \\
\hline Art 13 & Geografares & $\begin{array}{l}\text { - Geografia } \\
\text { - Administração pública e de empresas, ciências contábeis e } \\
\text { turismo } \\
\text { - Arquitetura, urbanismo e design } \\
\text { - Planejamento urbano e regional / demografia } \\
\text { - Sociologia }\end{array}$ & $\begin{array}{l}\text { B2 } \\
\text { B3 } \\
\text { B3 } \\
\text { B3 } \\
\text { B5 }\end{array}$ \\
\hline Art 14 & $\begin{array}{l}\text { Revista da } \\
\text { Católica }\end{array}$ & - Interdisciplinar & B4 \\
\hline Art 15 & $\begin{array}{l}\text { Risco: revista } \\
\text { de pesquisa } \\
\quad \text { em } \\
\text { arquitetura e } \\
\text { urbanismo }\end{array}$ & $\begin{array}{l}\text { - Arquitetura, urbanismo e design } \\
\text { - Planejamento urbano e regional / demografia }\end{array}$ & $\begin{array}{l}\text { B1 } \\
\text { B3 }\end{array}$ \\
\hline Art 16 & $\begin{array}{l}\text { Revista } \\
\text { Geográfica } \\
\text { Acadêmica }\end{array}$ & $\begin{array}{l}\text { - Planejamento urbano e regional / demografia } \\
\text { - Geografia }\end{array}$ & $\begin{array}{l}\text { B3 } \\
\text { B4 }\end{array}$ \\
\hline Art 17 & $\begin{array}{l}\text { Revista } \\
\text { Brasileira de } \\
\text { Estudos de } \\
\text { População }\end{array}$ & $\begin{array}{l}\text { - Planejamento urbano e regional / demografia } \\
\text { - Sociologia } \\
\text { - Administração pública e de empresas, ciências contábeis e } \\
\text { turismo }\end{array}$ & $\begin{array}{l}\text { A2 } \\
\text { A2 } \\
\text { B1 }\end{array}$ \\
\hline Art 18 & $\begin{array}{l}\text { Revista } \\
\text { Interdisciplin } \\
\quad \text { ar de } \\
\text { Sociologia e } \\
\text { Direito }\end{array}$ & $\begin{array}{l}\text { - Sociologia } \\
\text { - Planejamento urbano e regional / demografia }\end{array}$ & $\begin{array}{l}\text { B4 } \\
\text { B5 }\end{array}$ \\
\hline Art 19 & $\begin{array}{l}\text { Semina: } \\
\text { Ciências } \\
\text { Sociais e } \\
\text { Humanas }\end{array}$ & $\begin{array}{l}\text { - Administração pública e de empresas, ciências contábeis e } \\
\text { turismo } \\
\text { - Sociologia }\end{array}$ & $\begin{array}{l}\text { B5 } \\
\text { B5 }\end{array}$ \\
\hline Art 20 & $\begin{array}{l}\text { GEOUSP: } \\
\text { Espaço e } \\
\text { Tempo }\end{array}$ & $\begin{array}{l}\text { - Geografia } \\
\text { - Planejamento urbano e regional / demografia } \\
\text { - Arquitetura, urbanismo e design } \\
\text { - Administração pública e de empresas, ciências contábeis e } \\
\text { turismo }\end{array}$ & $\begin{array}{l}\text { A1 } \\
\text { B1 } \\
\text { B2 } \\
\text { B3 }\end{array}$ \\
\hline Art 21 & $\begin{array}{l}\text { Revista } \\
\text { UniVap }\end{array}$ & $\begin{array}{l}\text { - Planejamento urbano e regional / demografia } \\
\text { - Arquitetura, urbanismo e design } \\
\text { - Sociologia }\end{array}$ & $\begin{array}{l}\text { B3 } \\
\text { B5 } \\
\text { B5 }\end{array}$ \\
\hline Art 22 & $\begin{array}{l}\text { Psicologia \& } \\
\text { Sociedade }\end{array}$ & $\begin{array}{l}\text { - Sociologia } \\
\text { - Administração pública e de empresas, ciências contábeis e } \\
\text { turismo }\end{array}$ & $\begin{array}{l}\text { A2 } \\
\text { B2 }\end{array}$ \\
\hline Art 23 & $\begin{array}{c}\text { Acta } \\
\text { Geográfica }\end{array}$ & $\begin{array}{l}\text { - Planejamento urbano e regional / demografia } \\
\text { - Geografia } \\
\text { - Serviço social } \\
\text { - Administração pública e de empresas, ciências contábeis e } \\
\text { turismo } \\
\text { - Sociologia }\end{array}$ & $\begin{array}{l}\text { B1 } \\
\text { B1 } \\
\text { B2 } \\
\text { B3 } \\
\text { B3 }\end{array}$ \\
\hline Art 24 & $\begin{array}{l}\text { PRACS: } \\
\text { Revista } \\
\text { Eletrônica de }\end{array}$ & $\begin{array}{l}\text { - Planejamento urbano e regional/ demografia } \\
\text { - Administração pública e de empresas, ciências contábeis e } \\
\text { turismo }\end{array}$ & $\begin{array}{l}\text { B2 } \\
\text { B3 } \\
\text { B4 }\end{array}$ \\
\hline
\end{tabular}




\begin{tabular}{|c|c|c|c|}
\hline & $\begin{array}{l}\text { Humanidade } \\
\text { s do Curso } \\
\text { de Ciências } \\
\text { Sociais da } \\
\text { UNIFAP }\end{array}$ & $\begin{array}{l}\text { - Arquitetura, urbanismo e design } \\
\text { - Geografia } \\
\text { - Sociologia }\end{array}$ & $\begin{array}{l}\text { B4 } \\
\text { B5 }\end{array}$ \\
\hline Art 25 & $\begin{array}{l}\text { GEOUSP: } \\
\text { Espaço e } \\
\text { Tempo } \\
\text { (Online) }\end{array}$ & $\begin{array}{l}\text { - Geografia } \\
\text { - Planejamento urbano e regional / demografia } \\
\text { - Arquitetura, urbanismo e design } \\
\text { - Administração pública e de empresas, ciências contábeis e } \\
\text { turismo }\end{array}$ & $\begin{array}{l}\text { A1 } \\
\text { B1 } \\
\text { B2 } \\
\text { B3 }\end{array}$ \\
\hline Art 26 & $\begin{array}{l}\text { Revista } \\
\text { Espaço } \\
\text { Acadêmico }\end{array}$ & $\begin{array}{l}\text { - Planejamento urbano e regional / demografia } \\
\text { - Administração pública e de empresas, ciências contábeis e } \\
\text { turismo } \\
\text { - Arquitetura, urbanismo e design } \\
\text { - Serviço social }\end{array}$ & $\begin{array}{l}\text { B1 } \\
\text { B3 } \\
\text { B5 } \\
\text { B5 }\end{array}$ \\
\hline Art 27 & $\begin{array}{l}\text { OKARA: } \\
\text { Geografia } \\
\text { em Debate }\end{array}$ & $\begin{array}{l}\text { - Geografia } \\
\text { - Administração pública e de empresas, ciências contábeis e } \\
\text { turismo } \\
\text { - Sociologia }\end{array}$ & $\begin{array}{l}\text { B2 } \\
\text { B3 } \\
\text { B3 }\end{array}$ \\
\hline Art 28 & $\begin{array}{l}\text { Revista de } \\
\text { Ciências } \\
\text { Humanas }\end{array}$ & $\begin{array}{l}\text { - Planejamento urbano e regional/demografia } \\
\text { - Administração pública e de empresas, ciências contábeis e } \\
\text { turismo } \\
\text { - Serviço social }\end{array}$ & $\begin{array}{l}\text { B2 } \\
\text { B3 } \\
\text { B4 }\end{array}$ \\
\hline Art 29 & $\begin{array}{l}\text { Revista } \\
\text { Políticas } \\
\text { Públicas \& } \\
\text { Cidades }\end{array}$ & $\begin{array}{l}\text {-Administração pública e de empresas, ciências contábeis e } \\
\text { turismo - Planejamento urbano e regional / demografia } \\
\text { - Serviço social } \\
\text { - Geografia }\end{array}$ & $\begin{array}{l}\text { B3 } \\
\text { B3 } \\
\text { B4 } \\
\text { B5 }\end{array}$ \\
\hline Art 30 & $\begin{array}{l}\text { Geosaberes: } \\
\text { Revista de } \\
\text { Estudos } \\
\text { Geoeducacio } \\
\quad \text { nais }\end{array}$ & $\begin{array}{l}\text { - Geografia } \\
\text { - Administração pública e de empresas, ciências contábeis e } \\
\text { turismo } \\
\text { - Planejamento urbano e regional / demografia } \\
\text { - Arquitetura, urbanismo e design }\end{array}$ & $\begin{array}{l}\text { B2 } \\
\text { B3 } \\
\text { B4 } \\
\text { B5 }\end{array}$ \\
\hline Art 31 & $\begin{array}{c}\text { Acta } \\
\text { Geográfica }\end{array}$ & $\begin{array}{l}\text { - Planejamento urbano e regional / demografia } \\
\text { - Geografia } \\
\text { - Serviço social } \\
\text { - Administração pública e de empresas, ciências contábeis e } \\
\text { turismo } \\
\text { - Sociologia }\end{array}$ & $\begin{array}{l}\text { B1 } \\
\text { B1 } \\
\text { B2 } \\
\text { B3 } \\
\text { B3 }\end{array}$ \\
\hline Art 32 & $\begin{array}{l}\text { Revista } \\
\text { Monografias } \\
\text { Ambientais }\end{array}$ & $\begin{array}{l}\text { - Planejamento urbano e regional / demografia } \\
\text { - Administração pública e de empresas, ciências contábeis e } \\
\text { turismo } \\
\text { - Serviço social } \\
\text { - Geografia }\end{array}$ & $\begin{array}{l}\text { B2 } \\
\text { B5 } \\
\text { B5 } \\
\text { C }\end{array}$ \\
\hline Art 33 & Caderno $\mathrm{CRH}$ & $\begin{array}{l}\text { - Sociologia } \\
\text { - Planejamento urbano e regional / demografia } \\
\text { - Arquitetura, urbanismo e design } \\
\text { - Serviço social } \\
\text { - Administração pública e de empresas, ciências contábeis e } \\
\text { turismo }\end{array}$ & $\begin{array}{l}\text { A1 } \\
\text { A2 } \\
\text { A2 } \\
\text { A2 }\end{array}$ \\
\hline Art 34 & $\begin{array}{l}\text { Geosaberes: } \\
\text { Revista de }\end{array}$ & $\begin{array}{l}\text { - Geografia } \\
\text { - Administração pública e de empresas, ciências contábeis e }\end{array}$ & $\begin{array}{l}\text { B2 } \\
\text { B3 }\end{array}$ \\
\hline
\end{tabular}




\begin{tabular}{|c|c|c|c|}
\hline & $\begin{array}{c}\text { Estudos } \\
\text { Geoeducacio } \\
\text { nais }\end{array}$ & $\begin{array}{l}\text { turismo } \\
\text { - Planejamento urbano e regional / demografia } \\
\text { - Arquitetura, urbanismo e design }\end{array}$ & $\begin{array}{l}\text { B4 } \\
\text { B5 }\end{array}$ \\
\hline Art 35 & Revista FSA & $\begin{array}{l}\text { - Administração pública e de empresas, ciências contábeis e } \\
\text { turismo } \\
\text { - Serviço social } \\
\text { - Sociologia } \\
\text { - Geografia } \\
\text { - Planejamento urbano e regional / demografia }\end{array}$ & $\begin{array}{l}\text { B3 } \\
\text { B3 } \\
\text { B4 } \\
\text { B4 } \\
\text { B5 }\end{array}$ \\
\hline Art 36 & $\begin{array}{l}\text { Revista } \\
\text { Brasileira de } \\
\text { Planejament } \\
\text { o e } \\
\text { Desenvolvim } \\
\text { ento }\end{array}$ & $\begin{array}{l}\text { - Planejamento urbano e regional / demografia } \\
\text { - Administração pública e de empresas, ciências contábeis e } \\
\text { turismo }\end{array}$ & $\begin{array}{l}\text { B3 } \\
\text { B3 }\end{array}$ \\
\hline
\end{tabular}

Fonte: Elaboração própria com base em dados da pesquisa (2017)

Grande parte dos artigos, 15 no total, apresentam seu melhor Qualis na área de avaliação "Planejamento urbano e regional/demografia" e variam do estrato A2 (Revista Brasileira de Estudos de População e Revista Electrónica de Geografía y Ciencias Sociales) ao B3 (Revista Geográfica Acadêmica, Revista Univap e Revista Brasileira de Planejamento e Desenvolvimento). Em segundo lugar, 10 artigos apresentam seus melhores Qualis em área de avaliação "Geografia", variando de A1 (GEOUSP: Espaço e Tempo - Online) a B3 (Geografia em Atos). Em síntese, 24 dos 36 artigos apresentam suas melhores áreas de avaliação CAPES em "Planejamento urbano e regional/demografia" e em "Geografia". Em outras palavras, revela a coerência com os objetivos trabalhados nos artigos e as disciplinas que estudam esse fenômeno com as melhores áreas de avaliação CAPES.

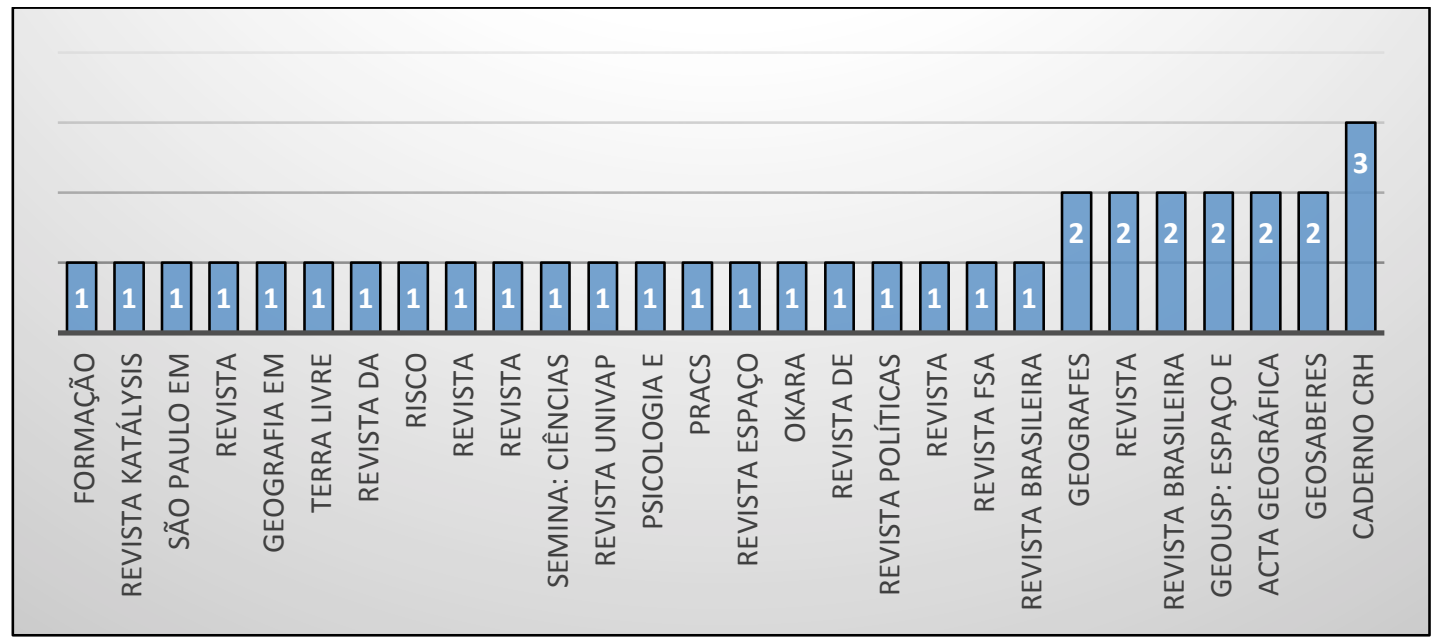

Figura 3: Periódicos e número de publicações

Fonte: Elaboração própria com base em dados da pesquisa (2017)

Ademais, os dados revelam que há uma grande diversidade de periódicos veiculando os trabalhos relacionados à temática (Figura 3). Em outras palavras, 28 diferentes periódicos veicularam os artigos aqui estudados. Contudo, 15 dos 36 artigos estão concentrados em 7 
periódicos, mostrando relativa concentração de publicação nessas revistas (Geografes, Revista Eletrônica de Geografia y Ciências Sociales, Revista Brasileira de Estudos de População, GEOUSP, Acta Geográfica, Geosaberes e Caderno $\mathrm{CRH}$ ). Ou seja, há uma pequena concentração, mas isso não parece ser um problema, uma vez que se percebe um grande número de periódicos interessados em publicar sobre a temática.

\subsection{Autores mais utilizados como referências bibliográficas}

Saber quais autores são mais utilizados como referências bibliográficas se torna extremamente útil para pesquisadores que buscam construir um referencial teórico sólido e que permita uma discussão bem embasada. Assim sendo, essa parte dos resultados busca ilustrar quais autores foram mais referenciados nos trabalhos analisados. Em suma, 13 autores se destacam como sendo os mais referenciados, ou seja, foram os mais recorridos pelos autores para embasar seus estudos. E dentre esses, um se destaca, Milton Santos, o qual foi referenciado em 14 dos 36 trabalhos analisados, revelando, assim, a importância de suas obras para a discussão da temática no cenário brasileiro.

Quadro 3: Autores mais referenciados nos trabalhos analisados

\begin{tabular}{|c|c|c|c|}
\hline Classificação & $\begin{array}{l}\text { Autores mais } \\
\text { utilizados como } \\
\text { referências }\end{array}$ & Artigos & $\begin{array}{l}\text { Número de } \\
\text { artigos que o } \\
\text { referenciaram }\end{array}$ \\
\hline 10 & SANTOS, Milton & $3 ; 8 ; 10 ; 11 ; 12 ; 13 ; 14 ; 15 ; 16 ; 19 ; 24 ; 25 ; 27 ; 31$ & 14 \\
\hline \multirow{2}{*}{ 20 } & VILLAÇA, Flávio & $3 ; 7 ; 11 ; 13 ; 15 ; 24 ; 26 ; 27 ; 28 ; 29 ; 31$ & \multirow{2}{*}{11} \\
\hline & MARICATO, Ermínia & $1 ; 3 ; 16 ; 18 ; 20 ; 21 ; 24 ; 32 ; 33 ; 35 ; 36$ & \\
\hline 3음 & LEFEBVRE, Henri & $1 ; 4 ; 10 ; 11 ; 14 ; 19 ; 20 ; 23 ; 24 ; 30$ & 10 \\
\hline 40 & HARVEY, David & $13 ; 17 ; 20 ; 23 ; 27 ; 31 ; 32 ; 33 ; 36$ & 9 \\
\hline \multirow{2}{*}{50} & CASTELLS, Manuel & $1 ; 11 ; 13 ; 14 ; 17 ; 20 ; 21 ; 24$ & \multirow{2}{*}{8} \\
\hline & CALDEIRA, Tereza & $1 ; 2 ; 6 ; 19 ; 21 ; 25 ; 30 ; 35$ & \\
\hline 60 & CARLOS, Ana Fani & $1 ; 3 ; 10 ; 11 ; 23 ; 24 ; 30$ & 7 \\
\hline \multirow{2}{*}{ 70 } & LOJKINE, Jean & $3 ; 4 ; 11 ; 12 ; 24 ; 35$ & \multirow{2}{*}{6} \\
\hline & KOWARICK, Lucio & $9 ; 10 ; 16 ; 29 ; 33 ; 36$ & \\
\hline \multirow{3}{*}{89} & ROLNIK, Raquel & $1 ; 16 ; 19 ; 24 ; 33$ & \multirow{3}{*}{5} \\
\hline & $\begin{array}{c}\text { SPOSITO, Maria E. } \\
\text { Beltrão }\end{array}$ & $1 ; 10 ; 11 ; 14 ; 34$ & \\
\hline & $\begin{array}{c}\text { CORRÊA, Roberto } \\
\text { Lobato }\end{array}$ & $3 ; 10 ; 11 ; 24 ; 31$ & \\
\hline
\end{tabular}

Fonte: Elaborado pelo autor com base em dados da Pesquisa (2017).

Outros autores, entretanto, se mostraram também relevantes para a discussão da temática, como é o caso dos brasileiros Flávio Villaça, Ermínia Maricato, Tereza Caldeira, Ana Fani Carlos, Lucio Kowarick, Raquel Rolnik, Maria Sposito e Roberto Lobato Corrêa, além de autores internacionais como Lefebvre, David Harvey, Manuel Castells e Jean Lojkine, utilizados como referência em um grande número de trabalhos, conforme descrição no Quadro 3 acima. 


\subsection{Análise do Corpus a partir do programa Iramuteq (Clusters e Fatorial)}

Nesse momento do trabalho serão expostos os resultados da análise do corpus, composta pelos resumos e introduções de todos os artigos, realizado a partir do uso do programa Iramuteq 0.7 Alpha 2. Observou-se após a geração dos dados que houve um aproveitamento de $84,87 \%$ do texto analisado, com um número de ocorrência de 26.373 e 747 segmentos de texto. Tal análise gerou 4 clusters, denominados de "temáticas das pesquisas", divididos em duas ramificações distintas, onde do lado esquerdo (viés empírico) encontra-se 2 clusters, divididos nas classes 2 (16,7\% dos segmentos de texto) e classe 1 (28,4\% dos segmentos de texto) respectivamente, e no lado direito (viés teórico), outros dois clusters, divididos em classe 4 (25,9\% dos segmentos de texto) e classe 3 ( $29 \%$ dos segmentos de texto), conforme dendograma na figura 4 abaixo.

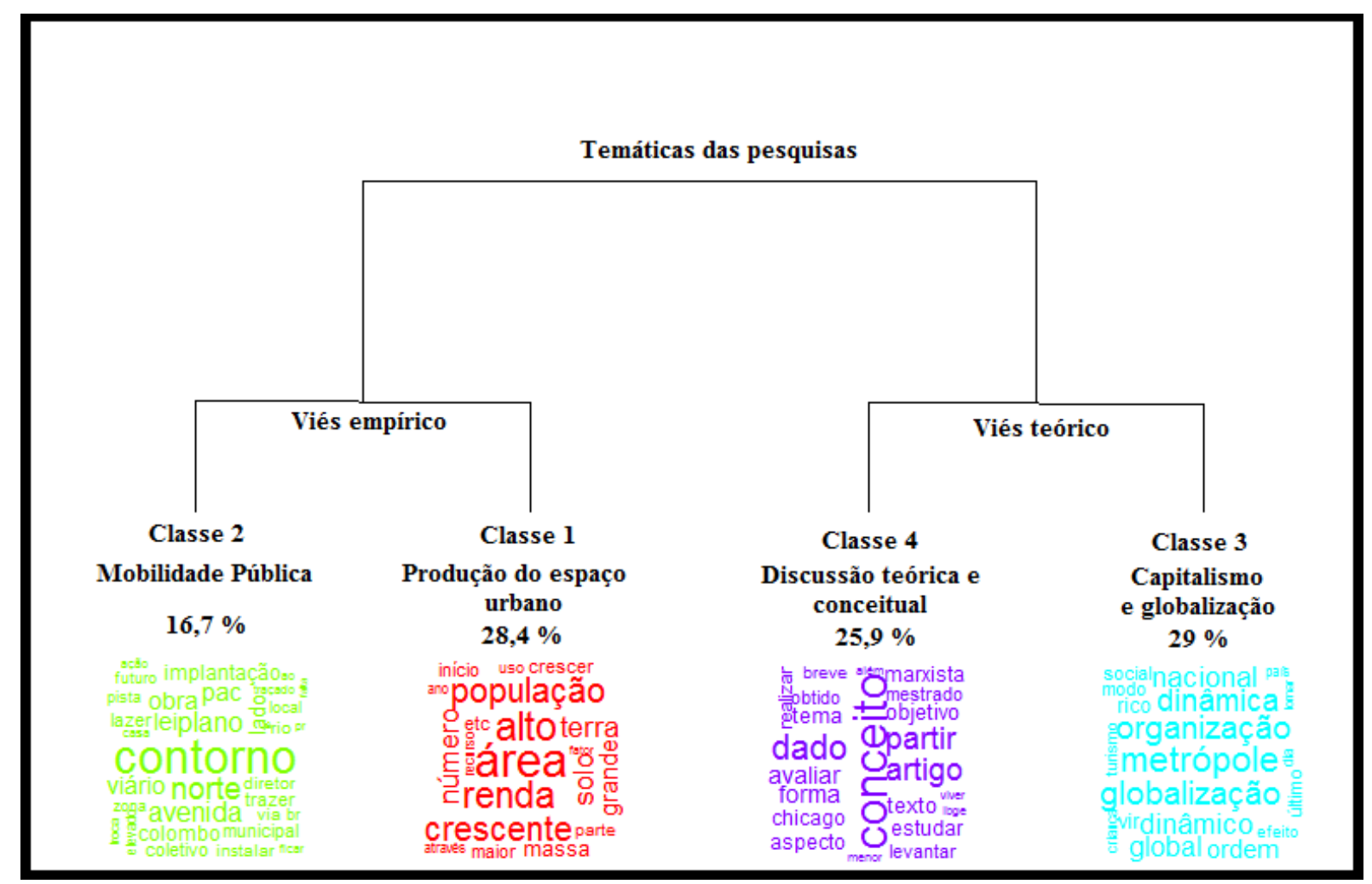

Figura 4: Dendograma.

Fonte: Elaboração própria com base em dados da pesquisa, 2017.

Na sequência foi realizada uma análise fatorial, que revelou através de suas informações, aqueles artigos e os anos que houveram concentrações semelhantes de assuntos, objetivos e temáticas através da associação das palavras dos seus respectivos textos. A Figura 5 abaixo mostra, de acordo com suas respectivas cores, os artigos e anos referentes aos clusters descritos acima. Observou-se que no primeiro quadrante encontram-se aqueles artigos e anos que trataram da classe 2 (verde) "Mobilidade Pública", ou seja, os artigos 23, 24, 26 e 33 e os anos 2012 e 2014 foram os que contribuíram para a classe 2, tendo como destaque as palavras: contorno, obra, avenida, viário, via e implantação para explicar as discussões sobre as intervenções em mobilidade urbana, em casos específicos, e seu impacto no processo de segregação socioespacial da cidade. No mesmo viés empírico, porém no quadrante 4, a classe 1 
(vermelha), denominada "Produção do espaço urbano" se trata de como está distribuído e sendo produzido o espaço urbano e seu efeito no processo de segregação que acontece nas cidades brasileiras. As palavras que aparecem para explicar essa classe são: uso, solo, população, renda, terra, entre outras. Os artigos que mais evidenciam essa associação de palavras são: 4, 8, 11, 16, 21, 25, 28, 29 e 32. Já os anos relativos a essa discussão foram: 2003, 2005, 2007, 2013 e 2016.

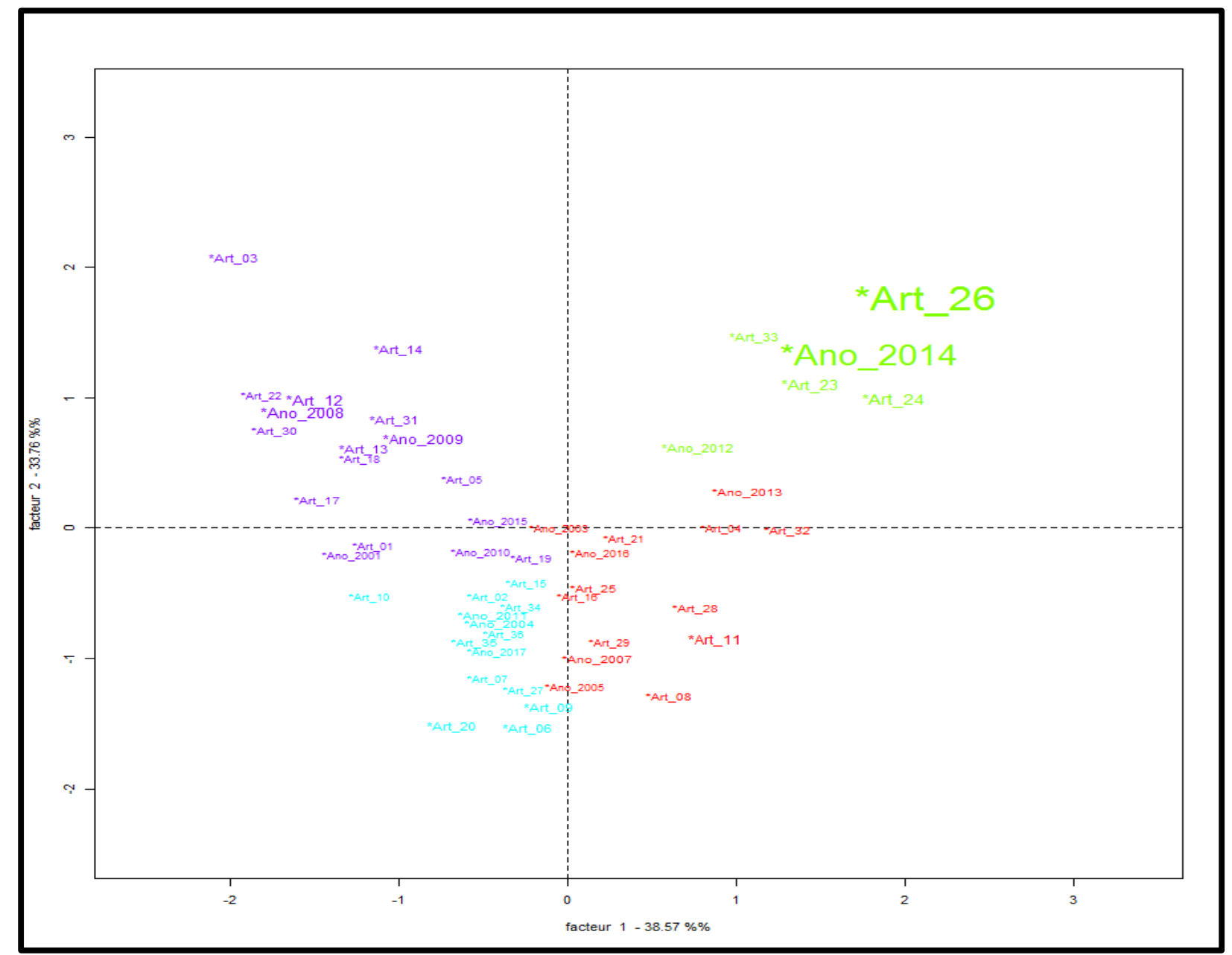

Figura 5: Análise fatorial de correspondência relativo aos artigos e anos de publicações Fonte: Gerado pelo programa Iramuteq com base em dados da pesquisa, 2017.

Por outro lado, no viés teórico, percebe-se no segundo quadrante os artigos que representam a classe 4 (roxo), denominada "Discussão teórica e conceitual". São eles: artigos 1, $3,5,12,13,14,17,18,19,22,30$ e 31 . E os anos os quais mais se evidenciou essa discussão foram: 2001, 2008, 2009, 2010 e 2015. Para explicar essa classe, as palavras que se destacaram foram: conceito, artigo, Chicago, marxista, texto, estudar, entre outras. Ou seja, esses artigos tratam da discussão do conceito em cada escola de pensamento, seja a de Chicago ou a marxista francesa, bem como tratam da produção de estudos e textos que contribuem para o enriquecimento teórico.

Ainda no viés teórico, temos a classe 3 (azul), a qual foi denominada "Capitalismo e globalização". Os artigos que formaram essa classe foram: 2, 6, 7, 9, 10, 15, 20, 27, 34, 35 e 36, e os anos de publicação foram: 2004, 2011 e 2017. Além disso, as palavras que contribuíram para a 
discussão da classe foram: globalização, metrópole, efeito, rico, social e dinâmica, pois tais trabalhos refletem teoricamente o efeito da globalização e do capitalismo no modo de vida e modo social das cidades, principalmente das metrópoles.

\section{CONSIDERAÇÕES FINAIS}

Por meio da utilização da meta-análise e do software Iramuteq, foi possível identificar um panorama sobre a realidade recente (2001 a 2017) das publicações no que se refere ao tema "segregação socioespacial" em revistas. Esse tipo de estudo tem uma grande vantagem: a sua capacidade de síntese de informações reunidas em um único trabalho.

Assim sendo, o trabalho permitiu observar que há uma diversidade de periódicos que veiculam a discussão sobre o assunto ( 28 no total). Há relativa concentração em 7 periódicos que veiculam 15 dos 36 artigos analisados. Entretanto, esse fato não é percebido como um problema, visto a diversidade de periódicos que se interessam pela discussão da temática. Nota-se também que, houve certa constância em publicações ao longo dos anos, média de 2 artigos por ano, porém destaca-se 2015 e 2016 os quais foram os anos que mais ocorreram publicações, talvez pelas grandes mudanças estruturais ocorridas no Brasil pelas obras da copa do mundo futebol em 2014 e olimpíadas do Rio de Janeiro em 2016.

Percebe-se também predominância de trabalhos com percursos metodológicos que se utilizam de pesquisa bibliográfica, a qual é essencial para a construção do referencial teórico, e a pesquisa documental, que, em síntese, é a reunião de dados que contribuem para discussão. Já em relação ao método, prevaleceram os estudos de caso e análises comparativas para revelar a situação do fenômeno.

Além disso, o uso do software Iramuteq se mostrou relevante para cumprimento do objetivo proposto, uma vez que permitiu identificação dos grupos de trabalhos, por meio de uma associação das suas palavras, criando 4 clusters que revelaram aquilo que esses grupos de trabalhos tinham em essência. Ou seja, revelou que ao longo dos anos analisados, houveram trabalhos com focos voltados para discussões teóricas e outros, com um viés mais empírico. Tal afirmação revela diversidade de caminhos metodológicos e teóricos para a pesquisa do fenômeno, o que é um elemento essencial para a pesquisa científica: a relação entre realidade e teoria.

Finalmente, este trabalho busca contribuir com o estudo sobre segregação socioespacial ao tentar elucidar de forma detalhada e sintética, dados contidos em trabalhos científicos, gerando assim, caminhos e aspectos que já estão sendo abordados e aqueles que ainda podem ser explorados em futuras pesquisas sobre a temática.

\section{REFERÊNCIAS}

ALMEIDA, E. T. V. (2017) A disputa pelo lixo e a resistência dos catadores em contextos de segregação socioespacial. R. bras. Planej. Desenv., Curitiba, v. 6, n. 2, p. 215-233, mai./ago. Disponível em: <https://periodicos.utfpr.edu.br/rbpd>. Acesso em: 23/08/2017.

BARBOSA, R. G. (2014) Planejamento urbano e segregação socioespacial na cidade de Macapá. PRACS: Revista Eletrônica de Humanidades do Curso de Ciências Sociais da UNIFAP, v. 6, n. 6, p. 135-148. 
BARTOLI, E. (2012) Segregação socioespacial e o direito à natureza urbana na cidade de manaus (Socio-spatial segregation and the right to urban nature in the city of Manaus). ACTA GEOGRÁFICA, v. 6, n. 11, p. 97-116.

BESERRA, M. R; TEIXEIRA, S. M. (2016) Urbanização e Segregação Socioespacial: O Papel do Estado no Planejamento Urbano/Urbanization and Socio-Spatial Segregation: The State's Role in Urban Planning. Revista FSA (Faculdade Santo Agostinho), v. 13, n. 3, p. 228-246.

BRASIL. Estatuto da Cidade. LEI $\mathrm{n}^{\circ}$ 10.257, de 10 de julho de 2001. Disponível em: http://www.planalto.gov.br/ccivil_03/leis/LEIS_2001/L10257.htm acesso em 14 de set de 2017.

BRASIL. MINISTÉRIO DAS CIDADES. Institucional; O ministério. Disponível em: http://www.cidades.gov.br/index.php/institucional/o-ministerio. Acessado em: 23 de agosto de 2017.

CAIADO, M. C. S. (2013) Estruturação intra-urbana na região do Distrito Federal e entorno: a mobilidade e a segregação socioespacial da população. Revista Brasileira de Estudos de População, v. 22, n. 1, p. 55-88.

CARDOSO, R. S; AMORIM, M. C. C. T. (2016) Análise do clima urbano a partir da segregação socioespacial e socioambiental em presidente prudente, SP, brasil. GEOSABERES-Revista de Estudos Geoeducacionais, v. 6, n. 3, p. 122-136.

CASTELLS, M. (1978) La questión urbana. 5 ed. Ciudad de Mexico, Siglo Veintiuno Editores S/A. . (1973) (org.) Imperialismo y Urbanizacion em America Latina.

DA ANUNCIAÇÃO ALVES, G. (2011) A segregação socioespacial na metrópole paulista. GEOUSP: Espaço e Tempo (Online), n. 29, p. 33-42.

DA CUNHA, J. M. P; JAKOB, A. A. E. (2016) Segregação socioespacial e inserção no mercado de trabalho na Região Metropolitana de Campinas. Anais, p. 1-29, 2016.

DA SILVA, A. F; DA SILVA, V P. (2003) Nos limites do viver: moradia e segregação socioespacial nas áreas metropolitanas do Nordeste brasileiro. Scripta Nova: revista electrónica de geografía y ciencias sociales, v. 7.

DA SILVA, J. M. P. (2009) Segregação socioespacial: contradições presentes em Palmas/TO. Risco: Revista de Pesquisa em Arquitetura e Urbanismo (Online), n. 9, p. 124-132.

DA SILVA, M. M. N et al. (2016) Segregação socioespacial: os impactos das desigualdades sociais frente a formação e ocupação do espaço urbano. Monografias Ambientais, v. 15, n. 1, p. 256-263.

DA SILVA, V. R. J. (2015) Segregação sócio-espacial na urbe carioca: o exemplo de campo grandeRJ. Acta Geográfica, v. 9, n. 19, p. 1-18.

DE ALMEIDA JÚNIOR, A. R; WHITACKER, A. M. (2011) Segregação Socioespacial em cidades médias: Diferenças ou Semelhanças? Um estudo sobre o Jardim Cinquentário e o Jardim Morada Do Sol em Presidente Prudente-SP. Geografia em Atos (Online), v. 2, n. 7.

FONTANA, F; VALOTTA, F. M. (2014) Projeto PAC "Contorno Norte" de Maringá: os impactos da obra e o aprofundamento do processo de segregação socioespacial na Região Metropolitana de Maringá. Revista Espaço Acadêmico, v. 13, n. 155, p. 106-122.

GONÇALVES, B. V. L. (2013) 0 direitos da criança e do adolescente à convivência comunitária: o ministério das cidades na institucionalização das políticas de combate à segregação socioespacial urbana. Confluências/ Revista Interdisciplinar de Sociologia e Direito, v. 11, n. 2, p. 141-152.

GOULART, J, O.; TERCI, E, T.; VANALE OTERO, E. (2016) Segregação socioespacial e política urbana em cidades médias no brasil contemporâneo (2001-2011). Caderno CRH, v. 29, n. 78. 
GUIMARÃES, M. C. R. (2015) Os movimentos sociais e a luta pelo direito à cidade no Brasil contemporâneo. Serv. Soc, n. 124, p. 721-745.

HUGHES, P. J. A. (2004) Segregação socioespacial e violência na cidade de São Paulo: referências para a formulação de políticas públicas. São Paulo em Perspectiva, v. 18, n. 4, p. 93-102.

LEFEBVRE, H. (1999). A cidade do capital. Rio de Janeiro: DP \& A.

LOJKINE, J. (1981) O estado capitalista e a questão urbana. São Paulo, Martins Fontes.

LOLIS, D. (2011) Homicídios de jovens e segregação socioespacial em Londrina. Semina: Ciências Sociais e Humanas, v. 31, n. 2, p. 221-240.

LUIZ, A. J. B. (2002) Meta-análise: definição, aplicações e sinergia com dados espaciais. Caderno de Ciências e Tecnologia, Brasília, v. 19, n. 3, p. 407-428.

LUZ, T. (2013). A abordagem do fenômeno urbano na Escola de Chicago. Lecturas Educación Física y Deportes (Buenos Aires), v. 185, p. 1.

MAGALHÃES, L. F. A; TONIN, V. H. (2015) Segregação socioespacial e luta por moradia na grande Florianópolis: raízes e características da Ocupação Contestado. Revista de Ciências Humanas, v. 49, n. 2, p. 224-255.

MARICATO, E. (1997) Reforma urbana: limites e possiblidades: uma trajetória incompleta. In: RIBEIRO, L. C. Q; SANTOS JR., O. A. (orgs.). Globalização, fragmentação e reforma urbana. Rio de Janeiro: Civilização Brasileira, p. 309-325.

- (2006) O Ministério das Cidades e a política nacional de desenvolvimento urbano.

MARINHO, T. P; SCHOR, T. (2009) Segregação socioespacial, dinâmica populacional e rede urbana na cidade de Parintins/AM. Geografares, n. 7.

MILANI, P. H; GÓES, E. M. (2015) Dentro e fora dos muros: residenciais fechados e segregação socioespacial em cidades não metropolitanas. GEOSABERES-Revista de Estudos Geoeducacionais, v. 6, n. 2, p. 260-274.

MIRANDA-RIBEIRO, A; GARCIA, R. A. (2005) Segregação socioespacial em Belo Horizonte: uma aplicação de modelos difusos. Revista Geografias, v. 1, n. 1, p. 86-97.

MOREIRA DE CARVALHO, I. M; SOUZA, A. G; PEREIRA, G. C. (2006) Polarização e Segregação Socioespacial em uma Metrópole Periférica. Caderno $C R H$, v. 17, n. 41.

MOREIRA DE CARVALHO, I. M; CORSO PEREIRA, G. (2007) Dinâmica metropolitana e segregação socioespacial. Caderno $C R H$, v. 20, n. 50.

OSMAR, H. R. S.; STEPHAN, I. I. C. (2015) Segregação na região metropolitana de belo horizonte: o estigma de Ribeirão das Neves/MG. Revista Políticas Públicas \& Cidades, v.3, n.2, p. 128144, mai/ago.

RODRIGUES, N. M. (2010) Segregação socioespacial e ações do plano diretor no bairro Maria Eugênia e a área central de viçosa. MG. Rev. Geogr. Acadêmica, v. 4, n. 1, p. 56-70.

ROMA, C. M. (2015) Segregação socioespacial interurbana: uma hipótese? Terra Livre, v. 2, n. 31.

ROSCOCHE, L. F. (2014) Turismo urbano e a segregação socioespacial: revisitando problemáticas. OKARA: Geografia em debate, v. 8, n. 1, p. 3-20.

SCHAEFFER, M. F. C. (2003) Segregação socioespacial no Distrito Federal. Revista Katálysis, v. 6, n. 2, p. 237-248.

SILVA, R. B. (2009) A segregação socioespacial urbana em Presidente Prudente (SP). Revista da Católica, Uberlândia, v. 1, n. 2, p. 81-104. 
SILVA DE CASTRO, E. A. (2012) Segregação socioespacial, constituição do sujeito e significação do cotidiano. Psicologia \& Sociedade, v. 24, n. 1.

SOGAME, M. (2001) Rudimentos para o exame da urbanização em sua fase crítica: uma aproximação ao conceito de segregação socioespacial. Geografares, n. 2.

SPOSITO, M. E. B. (2007) Reestruturação urbana e segregação socioespacial no interior paulista. Scripta Nova: revista electrónica de geografía y ciencias sociales, v. 11.

SURIANO, A. L. C; RESCHILIAN, P. R. (2012) Urbanização, habitação e segregação socioespacial.

Revista Univap, v. 18, n. 32, p. 190-202.

VELHO, O. G.(1987) O fenômeno urbano. 4ạ ed. Rio de janeiro: Ed. Guanabara.

VIEIRA, A. B; MELAZZO, E S. (2012). Introdução ao conceito de segregação socioespacial. Formação (Online), v. 1, n. 10.

VILLAÇA, F. (2001) Espaço intra-urbano no Brasil. São Paulo: Studio nobel: FAPESP.

ZOMIGHANI JR, J. H. (2013). Conexões geográficas e segregação socioespacial pelo uso das prisões no estado de São Paulo. GEOUSP: Espaço e Tempo (Online), n. 35, p. 97-114. 